\title{
Mechanism of Indigenous Rhizobacteria Isolate Growth Inhibition of Ganoderma boninense
}

\author{
Imam Rifai ${ }^{1}$, Yulmira Yanti ${ }^{2}$, Nurbailis ${ }^{2}$
}

\author{
${ }^{1}$ PostGradauated Pests and Plant Diseases of Faculty of Agriculture, Andalas University, Padang, West Sumatera, Indonesia \\ Email: imamrifai1396@gmail.com \\ ${ }^{2}$ Department of Plant Protection, Faculty of Agriculture, Andalas University, Padang, West Sumatera, Indonesia
}

\begin{abstract}
Basal stem rot (Ganoderma boninense) is the main disease of oil palm. Previous research results obtained 7 isolates of rhizobacteria indigenous which have the best ability to control G. boninense in oil palm seedlings and increase growth. The purpose of this study was to characterize the ability of PGPR and biocontrol of indigenous rhizobacteria isolates and inhibitory testing of $G$. boninense in vitro. Characterization methods include (Phosphate solubility, siderophore production, chitinase activity, hemolytic activity and dual culture test). The results showed four isolates of RZ1A 2.1, RZ2E 2.1, RZ1E 2.1, and RZ2B 1.1 were able to dissolve phosphate. only isolate RZ2B 1.1 produced siderophore. Two isolates produced chitinase RZ1E 2.1 and RZ2E 2.1. All isolates did not produce hemolysis. The best three isolates were obtained from RZ1E 2.1, RZ2E 2.1 and RZ2E 1.2 which have inhibitory properties against G.boninense.
\end{abstract}

Keywords - characterization, indigenous rhizobacteria, G. boninense.

\section{INTRODUCTION}

Oil palm (Elaeis guineensis Jacq.) is a monocotyledon from the family Arecaceae (formerly Palmae) within the subfamily Cocosoideae It is a major crop that grows in the tropical areas mainly in Southeast Asia. Palm oil is used worldwide for processing food, cosmetics, phar- maceuticals, biodiesel and in oleo chemical industry The high economic value and its role in the plantation sector has caused the oil palm commodity to be widely cultivated in various regions in Indonesia. The national productivity of oil palm is 3.6 tons / ha / year (Direktorat Jendral Perkebunan, 2017). The productivity is still very low when compared to the optimal productivity of oil palm which should be able to reach $7-8$ tons / ha / year (Fauzi et al., 2008).

One of the low productivity of oil palm plants is caused by plant pathogen attack. Basal Stem Rot (BSR) caused by Ganoderma boninense is a major disease in oil palm plantations in Southeast Asia including Indonesia (Chong et al., 2011). This disease is reported to cause losses of around 50-80\% per ha Indonesia and Malaysia are the countries with the largest losses due to BSR estimated at 500 million USD / year (Rees, Flood, Hasan, Wills, \& Cooper, 2012). BSR is difficult to control, because $G$. boninense is a soil-borne pathogen that has a wide range of hosts and has a special structure in the form of klamidospora and pseudosclerotia that have an impact on the ability to survive and infect target plant (Sanderson, 2005; Susanto et al., 2013).
Control efforts that have been made to $G$. boninense namely physical control through sanitation techniques, and using synthetic functions have not shown maximum results because they can cause negative impacts on the environment such as the killing of non-pathogenic organisms, causing human health problems, animals, and the occurrence of resistance to pathogens (Puspita et al., 2013). Alternative control of $G$. boninense that is safe for the environment is to use biocontrol agents from groups of microorganisms (Bivi et al., 2010). Microorganisms that have been widely reported as biocontrol agents are rizobacteria from the group Plant Growth Promothing Rhizobacteria (PGPR) (Beneduzi et al., 2012).

Rhizobacteria are a group of bacteria that can improve the quality of plant growth both directly and indirectly (Vishwakarma et al., 2018). Rhizobacteria exert antagonistic effects on plant pathogens in several ways, namely siderophore production, chitinase enzymes, parasitism, competition for nutritional sources, inducing systemic plant resistance and being able to dissolve phosphates which can increase the availability of nutrients for plant growth (Verma et al., 2010). Indigenous bacteria are better introduced to plants, because indigenous bacteria are more adaptable to the environment and more competitive than non-indigenous bacteria (Burelle et al., 2006:Yanti et al., 2013).

Control of soil borne pathogens with rhizobacteria has been reported to be effective, some rhizobacteria that have been reported to have the ability as 
biocontrol agents against $G$. boninense include Pseudomonas, Bacillus spp, and Burkholderia (Suryanto et al., 2012; Buana et al., 2014). Achromobacter, Bacillus, Burkholderia, Enterobacter, Ochrobactrum and Providencia genera were able to be both non-pathogenic and possessed the ability to colonize the host plant (Gowtham et al., 2018).

Previous research (Rifai, 2018) obtained 7 indigenous rhizobacteria isolates isolated from the roots of PTPN IV oil palm plantations in Simalungun Regency as a result of in planta selection has the best ability to increase growth and resistance of oil palm seedlings to BSR disease. These isolates still need to be characterized for their ability to control BSR disease caused by $G$. boninense. This study aims to characterize the ability of PGPR and biocontrol of indigenous rhizobacteria isolates and inhibitory testing of $G$. boninense in vitro.

\section{MATERIALS AND METHODS}

This research has been done as an experiment at Laboratory of Microbiology, Department of Plant Protection, Faculty of Agriculture, and Biomedical Laboratory Faculty of Medicine University of Andalas, Padang, Indonesia from Januari to April 2019.

In Vitro Characterization of PGPR and Biocontrol of Rhizobacteria Isolates

\section{a. Phosphate solubilization}

The isolates' ability to solubilize tri-calcium phosphate was assayed using methods of Wahyudi et al., (2011). The isolates was inoculated to Pikovskaya's Agar (Compositons per litre glucose 10g, Ca3 (PO4)2 5g, (NH4)2SO4 0.5g, KCl 0.2g,

\section{b. Siderophore Production}

Siderophore productions was determined using Chrome Azurol Sulphonate (CAS) agar medium described by (Husen, 2003). Each isolate was streaked on the surface of CAS agar medium and incubated at room temperature for 3 days. Siderophore production was indicated by orange halos around the colonies after the incubation.

\section{c. Chitinase Test}

Testing is done by dipping a $6 \mathrm{~mm}$ filter paper in indigenos rhizobacteria isolate suspension, then filter paper is placed on the surface of the media so that chitin is solid (15 g Bacto agar, $5 \mathrm{~g}$ glucose, $2 \mathrm{~g}$ peptone, $10 \mathrm{~g}$ colloidal chitin, $0.5 \mathrm{~g}$ K2HPO4, $0.5 \mathrm{~g} \mathrm{MgSO} 4,0.5 \mathrm{~g} \mathrm{NaCl}$ in 1 liter of distilled water (Cattelan et al., 1996).

\section{d. Hemolytic assay}

Hemolytic activity was determined using agar diffusion technique by Monteiro et al., (2005) namely by using Blood Agar (TSA enriched with 5\% of sheep blood $\mathrm{pH}$ of
7.3) where halo zone (hemolysis) around the colony observed as hemolytic activity.

\section{e. Antagonist in vitro test}

Rhizobacteria inhibition testing of G.boninense was carried out by the dual culture method by cutting G.boninense on a solid $5 \mathrm{~mm}$ diameter PDA using cork borer and placed on petridish containing mixed media (NA: PDA). Calculation of the radius of the colony was carried out at 7 days, until the Petri dish in the control treatment was fulfilled by $G$. boninense. The percentage of growth suppression of $G$. boninense is calculated by (Bivi et al., 2010).

$$
\mathrm{PIRG}=\frac{R 1-R 2}{R 1} \times 100 \%
$$

Where

$\mathrm{R} 1$ : radius of the $G$. boninense colony in the direction towards the antagonist colony

$\mathrm{R} 2$ : radius growth of $G$. boninense in the control plate

\section{RESULT}

Characteristics of PGPR and Biocontrol Indigenous Rhizobacteria Isolates

Rhizobacteria isolates of indigenous oil palm roots are character to determine their ability as Plant Growth Promothing Rhizobacteria (PGPR) and biocontrol in vitro. In this study, four rhizobacteria isolates of RZ1A 2.1, RZ2E 2.1, RZ1E 2.1, and RZ2B 1.1 were able to dissolve phosphate (table 1). This is indicated by the presence of clear zones produced by rhizobacteria isolates in Pikovskaya agar medium (Figure 1A). In this study, isolates that were able to dissolve adhesives were the Bacillus spp group. The Bacillus spp was group reported to have an advantage over other types of bacteria because it can excrete organic acids, such as formic acid, acetate and lactate which function to dissolve phosphate forms that are difficult to dissolve into forms available to plants so as to increase plant growth (Khan et al., 2009; Mehrab et al., 2010). Bacillus and Arthrobacter have ability solubilized phosphate (Vanissa et al., 2018).

Siderophore production showed that only isolate RZ2B 1.1 was able to produce siderophore with an orange zone around the disc paper on CAS media (Figure 1B). Siderophore production by rhizobacteria is one of the characters and a direct mechanism in suppressing the growth of pathogenic fungi. Siderophore directly stimulates the biosynthesis of antimicrobial compounds for the availability of minerals for bacteria that will suppress the growth of pathogens of $R$. solani and $F$. oxysporum which will induce the resistance of host plants (Wahyudi $e t$ al., 2011). The ability of bacteria to produce siderophore also an important component in PGPR, because 
siderophore are able to bind iron $(\mathrm{Fe} 3+)$ into siderophoriron bonds that become available to plant (Prihatiningsih et al., 2017; Ferreira et al., 2019). Bacterial siderophores have a higher affinity for $\mathrm{Fe}$ than phytosiderophores and are able to remove $\mathrm{Fe}$ from $\mathrm{Fe} 3+$-phytosiderophore complexes (Aguado-Santacruz et al., 2012).

Testing the activity of indigenous rizhobacteria chitinase isolates obtained two isolates of RZ1E 2.1 and RZ2C 2.1 (Table 2). Isolates are able to produce chitinase enzymes with clear zones on chitin agar media (Figure 1C). Chitinase enzymes produced by indigenous rhizobacteria isolates play a role in the degradation or lysis of chitin which is the structure of $G$. boninense fungal cell wall. In line with the research of Wibowo et al., (2017) which stated that 3 of 63 isolates of chitinase producing bacteria isolated from oil palm plantations showed three isolates TB04-05, SW0111, and SW02-08 were able to suppress the growth of $G$. boninense fungi. Azizah et al., (2015) also stated that Serratia marcescens KAHN 15.12 and B. amyloliquefaciens SAHA 12.07 are able to produce chitinase so that it can suppress the development of $G$. boninense fungal hyphae. Hemolysis activity showed that all isolates of negative activity did not form a hemilysis zone (table 1), meaning that it was not pathogenic in humans and animals, so it was safe to be used as a candidate for biologycal control agents (Figure 1D) Figueroa-Lopez et al., (2016) stated that pathogenic bacteria able to produce hemolysis so that it can cause disease for humans

\section{Antagonist in vitro test}

In vitro inhibition testing of rhizobacteria isolates against G.boninense in dual culture test showed six isolates were able to inhibit the growth of $G$. boniense with various inhibitory percentages at 7 days after inoculation. Three best rhizobacteria isolates were obtained, namely isolates RZ1E 2.1, RZ2E 2.1 and RZ2E 1.2.

Isolate RZ1E 2.1 has a high percentage of inhibition on the growth of $G$. boninense (Figure 2). Inhibition of growth of $G$. boniense with rhizobacteria in a dual culture test is thought to be influenced by the ability of rhizobacteria isolates to produce secondary metabolite compounds that can inhibit the growth of antifungal $G$. boninense fungi which is antifungal in accordance with the reported research (Bivi et al., 2010; Suryanto et al., 2012; Buana et al., 2014).

The mechanism responsible for the biocontrol activity of plant pathogenic fungi is through the production of antifungal compounds (Lee et al., 2015). The results of research Bakhtiar et al., (2012) reported that B. subtilis B10 isolated from oil palm roots was able to produce active compounds that are antifungal in order to suppress the growth of $G$. boninense in vitro. is antifungal so that it can suppress the growth of $G$. boninense in vitro. Other research results Parvin et al., (2016) confirmed that Pseudomonas aeruginosa isolated from palm oil rhizosphere produces metabolite products such as phenazine so that it can inhibit the growth of $G$. boninense. $P$. aeruginosa were able to inhibit $\mathrm{G}$. boninense growth with the percentage of inhibition radial growth (PIRG) values of $71.42 \%$ (Muniroh et al., 2019).

\section{FIGURES AND TABLES}

Table 1. Phosphate solubility, siderophore production, chitinase activity, and hemolytic activity of indigenous rhizobacteria isolates

\begin{tabular}{ccccc}
\hline Isolates & $\begin{array}{c}\text { Phosphate } \\
\text { solubility }\end{array}$ & $\begin{array}{c}\text { Siderophore } \\
\text { Production }\end{array}$ & $\begin{array}{c}\text { Chitinase } \\
\text { activity }\end{array}$ & $\begin{array}{c}\text { Hemolytic } \\
\text { activity }\end{array}$ \\
\hline RZ1A 2.1 & + & - & - & - \\
RZ2E 2.1 & + & - & + & - \\
RZ1E 2.1 & + & - & + & - \\
RZ2E 1.2 & - & - & - & - \\
RZ2C 2.1 & - & - & - & - \\
RZ2B 1.1 & + & + & - & - \\
RZIE 1.2 & - & - & - & - \\
\hline
\end{tabular}

Table 2. Percentage of inhibition ratio from rhizobacteria isolates against G.boninense growth in vitro

\begin{tabular}{lc}
\hline Isolates & PIRG (\%) \\
\hline RZ1E 2.1 & 70.22 \\
RZ2E 2.1 & 62.00 \\
RZ2E 1.2 & 45.50 \\
RZ2C 1.2 & 40.56 \\
RZ2B 1.1 & 40.00 \\
RZ1A 2.1 & 35.00 \\
RZ1E 1.2 & 0 \\
Control & 0 \\
\hline
\end{tabular}



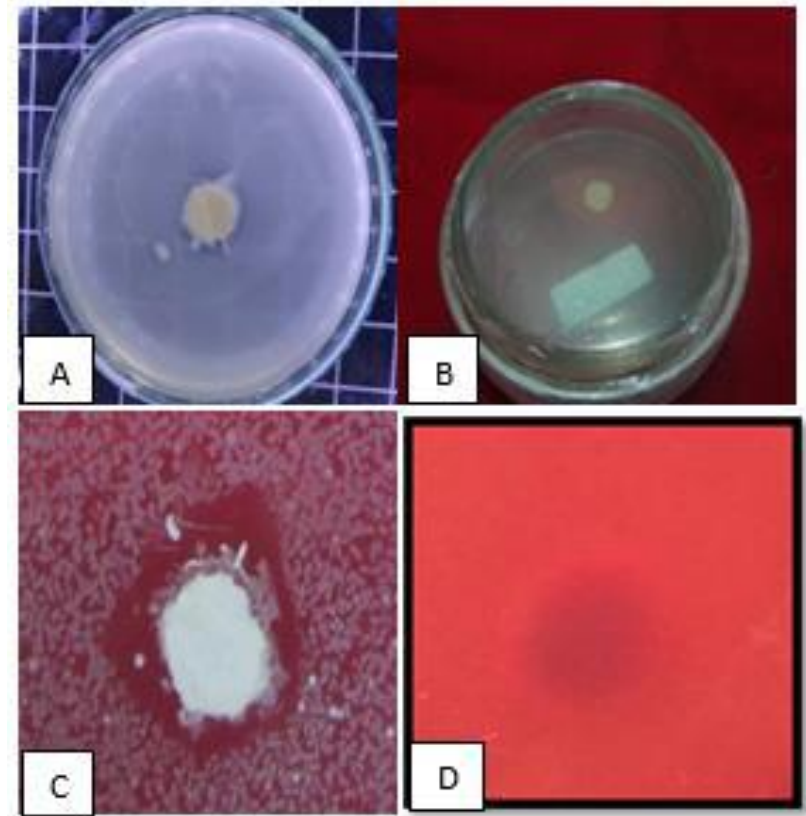

Fig.1: Character of indigenous rhizobacteria isolates (A) phosphate solubility $(B)$ siderophore production $(C)$ chitinase activity $(D)$ hemolytic activity.
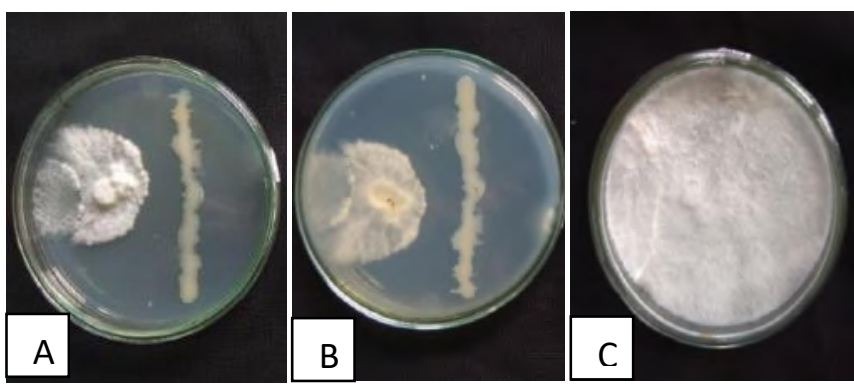

Fig.2: Effect of rhizobacteria isolates on the radial growth of $G$. boninense in the dual culture test (after 7 days of incubation) (A) Top, (B) bottom side of isolate RZ1E 2.1 and $(C) G$. boninense in control plate.

\section{CONCLUSION}

The results showed four isolates of RZ1A 2.1, RZ2E 2.1, RZ1E 2.1, and RZ2B 1.1 were able to dissolve phosphate. only isolate RZ2B 1.1 produced siderophore. Two isolates produced chitinase RZ1E 2.1 and RZ2E 2.1. All isolates did not produce hemolysis The best three isolates were obtained from RZ1E 2.1, RZ2E 2.1 and RZ2E 1.2 which have inhibitory properties against G.boninense

\section{REFERENCES}

[1] Aguado-Santacruz G A, Moreno-G'omez B, Jim' enezFrancisco B, Garc' 1a-Moya E, Preciado-Ortiz R E. 2012. Impact of the microbial siderophores and phytosiderophores on the iron as- similation by plants: Asynthesis. Rev Fitotec Mex. 35: 9-21.
[2] Azizah, S.N, Mubarik NR \& Sudirman LI. 2015. Potential of Chitinolytic Bacillus amyloliquefaciens SAHA 12 . 07 and Serratia marcescens KAHN 15.12 as Biocontrol Agents of Ganoderma boninense. Research Journal of Microbiology, 10 (10): 452-465.

[3] Bakhtiar, Y, Yahya S \& Sumaryono W. 2012. Adaptation of Oil Palm Seedlings Inoculated with Arbuscular Mycorrhizal Fungi and Mycorrhizal Endosymbiotic Bacteria Bacillus subtilis B10 towards Biotic Stress of Pathogen Ganoderma boninense Pat. Jurnal Microbiology Indonesia, 6 (4): 157-164.

[4] Beneduzi, A, Ambrosini, A \& Passaglia, L.M.P. 2012. Plant growth-promoting rhizobacteria ( PGPR ):Their potential as antagonists and biocontrol agents. Genetics and Molecular Biology, 4 : 1044-1051.

[5] Bivi, M.R, Farhana, M.S, Khairulmazmi, A \& Idris, A. 2010. Control of ganoderma boninense: A causal agent of basal stem rot disease in oil palm with endophyte bacteria in vitro. International Journal of Agriculture and Biology, 12 (6): 833-839.

[6] Buana, R.F.N, Wahyudi A.T, Toruan-Mathius N. 2014. Control activity of potential antifungal-producing Burkholderia sp. in suppressing Ganoderma growth in oil palm. A. J Agriculture Res.8(5):259-268. Asian Journal Of Agricultural Research, 8 (5): 259-268.

[7] Cattelan, A.J, Hartel, P.G \& Fuhrmann, J.J. 1996. Screening for plant growthpromoting rhizobacteria to promote early soybean growth. Soil Sci. Soc. Am. J, 63 : 1670-1680.

[8] Chong, K.P, Lum M.S, Foong, C.P, Wong, C.M.V.L, Atong, M \& Rossall, S. 2011. First identification of Ganoderma boninense isolated from Sabah based on PCR and sequence homology. African Journal of Biotechnology, 10 (66): 14718-14723.

[9] Ditjenbun] Direktorat Jendral Perkebunan. 2017. Pertumbuhan Areal Kelapa Sawit. [Diunduh 4 Mei 2018]..http://ditjenbun.pertanian.go.id/.2017.

[10] Fauzi, Y., Widyastuti, I., Sayawibawa, R., Hartono. 2008 Palm Oil (Cultivation of Product Utilization \& Waste Analysis of Business \& Marketing) Edition Revision Matter XXIII Penebar Swadaya. Bogor.

[11] Ferreira, M. J., Silva, H., \& Cunha, A. 2019. SiderophoreProducing Rhizobacteria as a Promising Tool for Empowering Plants to Cope with Iron Limitation in Saline Soils: A Review. Pedosphere: An International Journal, 29(4), 409-420. https://doi.org/10.1016/S10020160(19)60810-6

[12] Gowtham, H. G., Murali, M., Singh, S. B., Lakshmeesha, T. R., Murthy, K. N., Amruthesh, K. N., \& Niranjana, S. R. 2018. Plant growth promoting rhizobacteria Bacillus amyloliquefaciens improves plant growth and induces resistance in chilli against anthracnose disease. Biological Control.https://doi.org/10.1016/j.biocontrol.2018.05.022

[13] Husen, 2003. Screening Of Soil Bacteria For Plant Growth Promotion Activities In Vitro. Indonesian Journal of Agricultural Science, 4 (1): 27-31.

[14] Khan, A.A, Jilani, G, Akhtar, M.S, Naqvi, S.M.S. 2009. Phosphorus Solubilizing Bacteria: Occurrence, Mechanisms 
and their Role in Crop Production. J. Agric. Biol. Sci, 1 (1): $48-58$.

[15] Kokalis-burelle, N., Kloepper, J. W., \& Reddy, M. S. 2006. Plant growth-promoting rhizobacteria as transplant amendments and their effects on indigenous rhizosphere microorganisms. Applied Soil Ecology, 31, 91-100. https://doi.org/10.1016/j.apsoil.2005.03.007

[16] Lee, E, Chong K.P. 2015. Antimicrobial activity of Elaeis guineensis leaf extract against Ganoderma boninense of oil palm basal stem rot. J Pak Bot. 47(4):93-97.

[17] Mehrab, Y.H, Rahmani, A.N.G \& A A. 2010. Plant growth promoting rhizobacteria increase growth, yield and nitrogen fixation in Phaseolus vulgaris. Journal of Plant Nutrition, 33 (12): 1733-1743.

[18] Monteiro, L, Lima, R De, Mariano, R \& Souto-maior AM. 2005. Antagonism of Bacillus campestris pv . campestris Against Xanthomonas. Braz Arch Biol Technol, 48 (January): 23-29.

[19] Muniroh, M. S., Nusaibah, S. A., Vadamalai, G., \& Siddique, Y. 2019. Current Plant Biology Pro fi ciency of biocontrol agents as plant growth promoters and hydrolytic enzyme producers in Ganoderma boninense infected oil palm seedlings $\star$. Current Plant Biology, (July), 100116. https://doi.org/10.1016/j.cpb.2019.100116

[20] Parvin, W, Othman, R, Jaafar, H \& Wong, M. 2016. Detection of Phenazines from UPMP3 Strain of Pseudomonas aeruginosa and its Antagonistic Effects against Ganoderma boninense Detection of Phenazines from UPMP3 Strain of Pseudomonas aeruginosa and its Antagonistic Effects against Ganoderma boninense. International Journal of Agriculture and Biology, 18 (3): 483-488.

[21] Prihatiningsih, N, Djatmiko, H.A \& Lestari, P. 2017. Siderophore activity of Bacillus subtilis as plant growth promoters and biological control agent of eggplants pathogens. J. HPT Tropika, 17 (2): 170-178.

[22] Puspita, F, Zul, D K.A. 2013. Potential of Bacillus sp. The Origin of Giam Siak Kecil Bukit Batu as Rhizobacteria as a Growth and Antifungal promoter in Oil Palm Nursery. In , National Seminar on "The Role of Agricultural Technology and Institutions in Achieving Resilient and Sustainable Agricultural Development. National Seminar on "The Role of Agricultural Technology and Institutions in Achieving Resilient and Sustainable Agricultural Development.

[23] Rees, R.W, Flood, J, Hasan, Y, Wills, M.A \& Cooper, R.M. 2012. Ganoderma boninense basidiospores in oil palm plantations: Evaluation of their possible role in stem rots of Elaeis guineensis. Plant Pathology, 61 (3): 567-578.

[24] Rifai, I.2018. Screening Of Indigenous Rhizobacteria Isolates To Control Causes Of Diseases Basal Stem Rot (Ganoderma boninense) On Pre Nursery Oil Palm (Elaeis guineensis Jacq.) $\mathrm{p}$

[25] Sanderson, F.R. 2005. An insight into spore dispersal of Ganoderma boninense on oil palm. 139-140 p

[26] Suryanto, D, Wibowo, R.H, Siregar, E.B.M . 2012. A possibility of chitinolytic bacteria utilization to control basal stems disease caused by Ganoderma boninense in oil palm seedling. African Journal of Microbiology Research, 6 (9): 2053-2059.

[27] Susanto, A, Prasetyo, A.E, Priwiratama H \& Wening S. 2013. Ganoderma boninense as Causal Agent of Upper Stem Rot Disease of Oil Palm. 9 (51): 123-126.

[28] Vanissa, G., Tchakounté, T., Berger, B., Patz, S., \& Fankem, H. 2018. Community structure and plant growthpromoting potential of cultivable bacteria isolated from Cameroon soil. Microbiological Research, 214(January), 47-59. https://doi.org/10.1016/j.micres.2018.05.008

[29] Verma, J.P., Yadav J., Tiwari K.N., Lavakush \& singh V. 2010. Impact of Plant Growth Promoting Rhizobacteria on Crop Production. International Journal of Agriculture Research, 5 (11): 954-983.

[30] Vishwakarma, K, Kumar, V, Tripathi, D.K \& Sharma, S. 2018. Characterization of rhizobacterial isolates from Brassica juncea for multitrait plant growth promotion and their viability studies on carriers. Journal Environmental Sustainability, 1 (3): 253-265.

[31] Wahyudi, A.T, Astuti, R.P, Widyawati, A \& Meryandini A. 2011. Characterization of Bacillus sp . strains isolated from rhizosphere of soybean plants for their use as potential plant growth for promoting Rhizobacteria. Journal of Microbiology and Antimicrobials, 3 (2): 34-40.

[32] Wibowo, R.H, Mubarik, N.R, Rusmana, I \& Thenawidjaya, M. 2017. Screening and Identification of Chitinolitic Bacteria Inhibiting Ganoderma boninense in Vitro. Jurnal Fitopatologi Indonesia, 13 (3): 105-111.

[33] Yanti, Y, Habazar, T, Resti, Z \& Suhalita, D. 2013. Screening of indigenous rhizobacteria from healthy soybean root to control bacterial pustule (Xanthomonas axonopodis pv. glycines) using in planta technique. J. HPT Tropika., 13 (1): 24-34. 